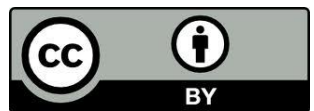

\title{
O MONAQUISMO NO OCIDENTE: CONSIDERAÇÕES SOBRE HISTÓRIA
}

\author{
Western Monasticism: historical considerations
}

\author{
Wilma de Lara Bueno \\ Universidade Tuiuti do Paraná \\ e-mail: buenofamilia@uol.com.br
}

\begin{abstract}
RESUMO: Do Oriente ao Ocidente, o monaquismo tornou-se um modelo de religiosidade e de organização da vida comunitária que serviu de orientação para os ideais religiosos da Igreja Católica, a partir do empenho de homens que lhes deram voz e se debruçaram sobre as estratégias de expansão do cristianismo. Os monges lograram um lugar de destaque na sociedade europeia ocidental em tempo de institucionalização da Igreja Católica e contribuíram, efetivamente, com as práticas cotidianas que se fundamentavam nos preceitos ore et labore. Para além de fornecerem um modelo de organização fundamentada no trabalho e na oração, os monges foram os responsáveis pela preservação dos documentos, traduções de obras clássicas e constituição de bibliotecas, o que fez dos mosteiros centros de religiosidade, cultura, educação e produção da vida material.
\end{abstract}

Palavras-chave: Igreja Católica ; Monaquismo ; Ocidente ; Religiosidade.

ABSTRACT: From East to West, monasticism is a religious model and an organizer of community life. It serves as orientation for the religious ideals of the Catholic Church and stems from the commitment of the men who used their voices and poured themselves over the expansion plans of Christianity. The monks succeeded to a prominent place in Western European society in a time of institutionalization in the Catholic Church. They contributed effectively to the daily practices that were based on o re et labore precepts. In addition to providing an organizational model based on work and prayer, the monks were responsible for the preservation of documents, translations of classic works, and the establishment of libraries, which made their monasteries affluent centers of religion, culture, education as well as the producers of life matter.

Keywords: The Catholic; Church monasticism ;West Religiousness. 


\section{Introdução}

O presente artigo apresenta alguns aspectos históricos sobre origem do monaquismo no Ocidente, no sentido de se buscarem as primeiras experiências que inspiraram os cristãos e os levaram a adotar seus fundamentos em organizações cenobíticas criadas no contexto de institucionalização da Igreja Católica, em tempo de crise generalizada, decorrente das invasões do século V. A partir da fundação dos primeiros mosteiros e do reconhecimento de sua potencialidade explicitada na máxima ore et labore, o papa São Gregório Magno (540-604) incentivou intensamente a expansão desse modelo de organização às mais distantes regiões, contribuindo, eficazmente, para o fortalecimento da religiosidade e da posição da Igreja Católica no mundo ocidental.

Nesse sentido, para atender aos propósitos desta publicação, a reflexão inicia com a abordagem das mais variadas experiências dos monges do deserto às que se estruturaram e conceberam uma regra para orientar a vida comunitária, em regiões que atualmente são ocupadas por países no Oriente Médio. Do Oriente ao Ocidente, o modelo de vivência cenobítica foi transportado por peregrinos e viajantes diversos e contou com a devoção de personagens da Igreja que lhe deram vigor e significados, encontrando um público atento que compartilhou e comungou com tais propósitos.

\section{Do Oriente ao triunfo do Monaquismo no Ocidente}

Pensar as origens do monaquismo no Ocidente significa recuperar suas manifestações iniciais de expressividades muito variadas, situando-as no século III em territórios ocupados pelos povos egípcios, sírios, palestinos entre outras etnias, particularmente, nos desertos da Ásia Menor, como era conhecida a região naquela época. Inicialmente, a prática da ascese ou a busca da solidão no deserto, era realizada por adeptos das mais diversas intenções. Entre os que comungavam desta opção de vida estavam aqueles que fugiam dos pagamentos dos impostos, ou aqueles que encontravam no deserto uma forma de se livrar do jugo das autoridades e do conjunto de leis que incidiam sobre a população e a obrigava à obediência e ao cumprimento dos deveres do 
Estado. Essas pessoas buscavam, entre outros motivos, chamar atenção das autoridades e da população em geral, entregando-se aos exercícios de mortificação, realizando jejuns prolongados, exibindo despojamento no vestir ou no pentear, evidenciando, desta forma, um abandono às vaidades e desapego dos bens materiais. Entre esse público, os estilitas $^{1}$, por exemplo, habitavam os cumes das árvores, das pedras ou dos rochedos; dormiam em grutas ou em túmulos abandonados. Muitos apresentavam aspectos rudes e toscos, deixavam os cabelos e barbas compridas, usavam apenas parcas peles ou restos de vestimentas. Alguns representantes chamavam atenção pelos conselhos e promessas de paz que revelavam aos que os procuravam.

Nesse contexto, a solidão no deserto era um hábito masculino e entendido também como um movimento marginal, uma vez que entre seus adeptos estavam pessoas malvistas e em débito com as responsabilidades civis. ${ }^{2}$ Por essa razão, associavam-se a bandidos, assassinos, foragidos do sistema militar e da justiça das autoridades. Esses personagens eram por vezes convocados por lideranças para fazer presença na realização dos concílios cristãos e desta forma desviar as atenções dos participantes, invertendo ou até mesmo desfazendo a ordem. Por essa razão, incomodavam a igreja e não eram bem visto pelos representantes do clero. Entre os monges havia ainda os que se manifestavam contrários ao modelo de vivência cristã que estava sendo definido pela nascente Igreja romana, e pretendiam o retorno ao cristianismo primitivo.

Dessa maneira, a busca de solidão no deserto contou também com a adesão de pessoas interessadas em reviver um autêntico modelo de religiosidade sugerido pelas comunidades cristãs que demonstravam esmero em seguir as pegadas do fundador do cristianismo. Da mesma forma que Jesus Cristo havia se retirado para o deserto e se submetido as mais duras provas de crescimento do espírito, os ascetas ${ }^{3}$ procuravam a

\footnotetext{
${ }^{1}$ Vem do grego stylos, que quer dizer coluna. Monge instalado sobre uma pequena plataforma no alto de uma coluna ao ar livre. In: BERLIOZ, Jacques. Monges e religiosos na Idade Média. Lisboa: Terramar, 1994, p. 182.

${ }^{2} \mathrm{Na}$ Antiguidade, a vida no deserto não era própria para as mulheres, não existindo mulheres eremitas ou estilitas. "As grutas, as montanhas selvagens e os desertos infestados de demônios são a morada dos solitários barbudos. São Jerônimo proibe o eremitismo às mulheres pois 'seu pensamento mutável e flutuante desliza facilmente para o pior". GATIER, Pierre Louis. Mulheres no deserto? In: BERLIOZ, Jacques. Monges e religiosos na Idade Média. Lisboa: Terramar, 1994, p. 172.

${ }^{3}$ Ascese vem da palavra grega askesis e significa se exceder. Na sua origem, a palavra ascese é uma palavra do vocabulário militar romano. Ela indica duas realidades largamente diferentes: o conjunto de exercícios praticados em vista de um aperfeiçoamento físico. O sentido da palavra alargou-se para designar todo esforço ou método para o aprimoramento dos domínios físicos, morais, intelectuais ou
} 
solidão como um caminho para viver a autêntica mensagem evangélica. Assim, entre os anacoretas, em sua fase inicial, encontravam-se, igualmente, aqueles partidários das mais profundas intenções de satisfazer sua ânsia de religiosidade.

No transcorrer dessas evidências, as comunidades passaram a contar com o trabalho de lideranças dotadas de um projeto de vida comum que associava o ideal religioso às experiências cenobíticas. Dessa maneira, ocorreram mudanças significativas no modelo de organização à medida que passaram a reunir pessoas em cenóbios, doutrinando-as para a vivência coletiva, tendo uma regra que disciplinava o trabalho, as práticas de piedade e possibilitava ainda um retorno econômico. Estudioso sobre o assunto confirma:

en el monacato primitivo las das figuras claves son san Antonio (c.250-376), que es considerado el fundador del monacato cristiano, y que se retiró al desierto egipcio hacia el año 270; Basilio de Cesarea, muerto em el año 378, y dedicado a la vida monástica desde el año 358. El tercer personaje clave es Pacomio, que pratica la vida monacal a partir del año $320 " .4$

Em se tratando dessas experiências comunitárias toma-se como exemplo as que foram dirigidas por São Pacômio (292-346). Ele buscou organizar os indivíduos isolados do deserto e apresentar-lhes as vantagens da vida comunitária. Os adeptos de seu projeto viviam em koinonia (do grego koinos, que quer dizer, comunhão) em número de vinte pessoas aproximadamente, distribuídas em celas individuais ou compartilhadas com mais um integrante. Na comunidade, trabalhavam na cozinha e praticavam o artesanato, tais como carpintaria, produção têxtil, entre outros tipos de trabalhos manuais. Todas as unidades eram munidas de biblioteca; cuidava-se da instrução e da cultura dos integrantes, uma vez que entre os mais antigos habitantes do

espirituais. Na Escritura Sagrada, não há um método prescrito para progredir na vida espiritual. Mas, São João Batista pregava a austeridade e São Paulo, no domínio espiritual, enaltece a luta, o combate, a preparação na maneira do esporte. $O$ esforço para ser fiel a Deus supõe a abnegação, a renúncia, a aceitação do sofrimento, de superar o medo. Esse conjunto de comportamento que são chamados de ascese cristã. (NOUVELLE ENCYCLOPÉDIE CATHOLIQUE: Théo: recherches de Dieu Patrimoine judéo-chrétien; vie e foi de l'église. Paris: Droguet\& Ardant/Fayard, 1989, 735). No entanto, a ascese foi praticada por povos não cristãos e de etnias diversa: entre os hebreus os naziritas, essênios e terapeutas; entre os hindus, os adeptos do estado de beatitude praticavam a ascese para alcançar o nirvana; entre os muçulmanos há um tipo de movimento místico denominado sufismo.

${ }^{4}$ BLÁZQUEZ, J. M. Orígenes del monacato cristiano. In: ALVAR, Jaime; BLÁZQUEZ, José Maria; ARDANAZ, Santiago F.; MONTEAGUDO, Guadalupe Lopez; LOZANO, Arminda; PIÑERO, Antonio. Cristianismo primitivo y religiones mistéricas. Madrid: Ediciones Cátedra, 1995, p.381. 
deserto muitos eram analfabetos. Assim, dominando a leitura, os monges estudavam as Sagradas Escrituras, recitavam os salmos e seguiam uma regra, instituída por São Pacômio. Os estudiosos afirmam que essa regra era mais suave do que as demonstradas pelas experiências anacoretas isoladas. ${ }^{5}$

No modelo de organização idealizada e experimentada por São Pacômio, cada unidade se especializava em um determinado serviço, sendo controlada por um responsável, que por sua vez dependia do fundador, esboçando-se, dessa maneira, os fundamentos hierárquicos do monaquismo nascente. Pacômio não se ordenou sacerdote, mantendo uma concepção de cristianismo diferente da Igreja oficial do século III, vinculando-se ao mundo rural e laico. Esta característica do monaquismo primitivo chama atenção à medida que a Igreja, que se constituía a partir dos primeiros apóstolos, Pedro e Paulo, revelava-se mais com um perfil urbano do que rural; mais institucional do que laico.

Assim como São Pacômio, São Basílio de Cesaréia (329-379) também fundou uma comunidade, a partir do ano de 360, contando com vários adeptos. Estabeleceu uma regra com os princípios da vida comum e um rol de ocupações para o monge. Ele escreveu uma Grande Regra e uma Pequena Regra para a vida monástica em que as atividades do monge seriam distribuídas entre o trabalho, estudo e oração, pelo que foi considerado o "legislador do monaquismo oriental". Porém, as regras seriam mais de cunho moral e não jurídico, orientando a formação de uma comunidade aristocrática e culta. Já São Basílio teria tido uma formação cultural como seguidor das ideias dos teólogos e filósofos de Alexandria, onde se discutiam os clássicos da antiguidade grega. Contudo, seus dados biográficos revelam, igualmente, que ele teria se dedicado ao ensino, fundando escolas; enfatizam que entre os membros de sua comunidade existiam muitos integrantes pobres e analfabetos; também não trabalhavam na agricultura e viviam da caridade ofertada pela comunidade circundante, revelando um padrão de pobreza considerável.

\footnotetext{
${ }^{5}$ Anacoreta vem da palavra anachoresis, ação conjunta de se retirar e de se refugiar, é, na origem, a fuga dos camponeses egípcios que, para escaparem aos encargos, em particular fiscais, que os esmagavam, se refugiam em lugares desérticos ou nos pântanos do Delta. A anacorese, esse abandono, virá a tornar-se o esforço constante do monge, o anacoreta, para se desapegar do mundo que deixou. GATIER, Pierre Louis. Mulheres no deserto? In: BERLIOZ, Jacques. Monges e religiosos na Idade Média. Lisboa: Terramar, 1994, p. 183
} 
Estudiosos dessa temática afirmam que o monaquismo dos primeiros tempos, mesmo apresentando a característica de um modelo de vida isolada no deserto e em lugares longínquos, não pode ser desvinculado da sociedade de seu tempo e da dinâmica que sustentava a estrutura sociopolítica daquela época. Embora apresentem visões diferenciadas, entendem que o monaquismo, em suas origens, esteve associado às diversas intenções, prevalecendo a marginalidade de muitos de seus representantes e a realização de manifestações de rebeldia e de desacato às autoridades. Também consideram que não foi um movimento exclusivamente cristão, pois entre os primeiros monges existiam pessoas leigas, sem nenhum vínculo com religião instituída. Isto quer dizer que a busca da solidão no deserto, na condição de eremita, ${ }^{6}$ não seria privilégio do clero e que o monaquismo ocorreu em diversas regiões dominada pelo Império Romano, apresentando configurações variadas, sendo também um movimento de oposição à Igreja:

Mas o monaquismo (...) ele só aparece no final do século III, no momento em que se interrompem as perseguições aos cristãos no Império Romano e em que as comunidades cristãs se alargam, passando para a dimensão da seita à sociedade inteira. O monaquismo começa por ser uma reação a esta última evolução: mostra a vontade de conservar um ideal religioso, nascido nas perseguições, não convertendo lentamente a sociedade greco-romana como a Igreja se aplica a fazer; mas isolando-se dessa sociedade e rejeitando os compromissos a que ela obriga os cristãos. ${ }^{7}$

Dessa forma, torna-se interessante conhecer como uma opção de vida que se manifestava de maneiras tão variadas tornou-se um movimento significativo e uma prática comum do mundo cristão e católico, instituindo-se no Ocidente, durante o período medieval. Também essa constatação vem sendo pesquisada de forma particular por historiadores, sociólogos e estudiosos da religião. Em parte, as explicações buscam superar as limitações procedentes da ausência de documentação, das lacunas provocadas por fontes esparsas, da precariedade de dados e da complexidade proveniente das influências étnicas e religiosas variadas que efetivamente marcaram o final da antiguidade.

No caso da presente pesquisa, para se compreender como o monaquismo passou

\footnotetext{
${ }^{6}$ Eremita, do grego, eremos, que quer dizer deserto. Os primeiros eremitas retiravam-se para o deserto egípcio, em condições de vida extremamente rudes. ( NOUVELLE... 1989, p.330).

${ }^{7}$ Ibidem, p. 170.
} 
a fazer parte da Igreja e se desenvolveu durante o período medieval é necessário dialogar com as origens institucionais cristãs no mundo ocidental e situar o lugar que a ascese ocupou nessa trajetória, quando de movimento isolado e marginal, tornou-se o centro da vida religiosa cristã medieval. Ou seja, recuperar como se deu o deslocamento dessas primeiras experiências anacoretas e ou cenobíticas do Oriente Médio para o Ocidente na fase de decomposição do Império Romano e institucionalização da Igreja Medieval.

Para se compreender esses dois movimentos - a instituição da Igreja Católica e a edificação dos primeiros mosteiros na Europa Ocidental - que se relacionam, mas que constroem trajetórias distintas considera-se que o Baixo Império Romano ou a Antiguidade Tardia conviveu com uma pluralidade de correntes filosóficas e religiosas que defendiam concepções diversas, lutavam para se estabelecer e revelarem-se verdadeiras.

A partir das comunidades constituídas pelos primeiros apóstolos, em que Pedro e Paulo ocuparam um lugar de destaque, o primeiro por ser o sucessor de Jesus, e o segundo por ser um intelectual militante na pregação do evangelho, o propósito e a urgência de expansão da boa nova entre os pagãos exigiram a criação dos cargos de diácono, presbítero e bispo. Esses cargos não se diferenciavam acentuadamente, podendo significar as mesmas funções. O interessante é destacar que, munidos de tais atributos, esses clérigos passavam a cuidar da religiosidade dos grupos, bem como dos aspectos jurídicos, econômicos, sociais e morais dos grupos sociais. Com isso, ocuparam um lugar de destaque no centro das vilas e dos agrupamentos humanos, sendo reconhecidos e respeitados como autoridades. Cabe destacar que essas lideranças nem sempre possuíam uma formação adequada e por vezes até desconheciam os fundamentos da religiosidade que professavam. Isto porque os cânones idealizadores do comportamento e da ética cristã ainda se encontravam em fase de elaboração, sendo discutido o que se poderia considerar como relevante para o cristianismo e o que deveria ser evitado procedente, por exemplo, da prática do judaísmo. Ou seja, os edificadores da Igreja Católica, nos primeiros tempos de sua institucionalização, enfrentaram dificuldades em selecionar o conjunto de práticas que passaria a fazer parte do mundo cristão e o que seria abandonado como outra forma de religiosidade ou mesmo como atitude pagã. Nesse sentido, já no tempo de Paulo, em 49 da era cristã, foi realizado o 
primeiro Concílio de Jerusalém ${ }^{8}$, oportunidade em que o assunto mais discutido foi a prática da circuncisão.

Não foi tarefa fácil definir esses fundamentos para projetar o cristianismo e fundar a Igreja como uma instituição reconhecida, dotada de um corpo eclesiástico coeso, em meio à complexidade dos fatores de ordem diversa. Há que se ter presente que os tempos também exigiam decisões acertadas ante as concorrências de inúmeras seitas e movimentos localizados em vários pontos do Império. Por outro lado, o processo histórico de conquistas alexandrinas e a helenização do Oriente corroboraram, igualmente, para a difusão da língua grega e do pensamento filosófico helenístico, em que se destacaram o estoicismo e seus adeptos. Esse movimento favoreceu a formação de um comportamento de interiorização ou introspecção: entre grupos e pessoas verificava-se um desejo de voltar-se às questões das finalidades do homem e seu comportamento perante a vida e sua trajetória. Havia, então, um clima favorável à adesão de formas de religiosidade que correspondessem aos anseios humanos e projetassem um significado convincente. Da mesma forma, o estudo dos filósofos pagãos parecia apresentar o ponto de partida para se pensar o lugar do homem e sua atitude num mundo alterado por fatores diversos. Das antigas cidades, centros culturais por excelência, - como, por exemplo, Alexandria -, surgiam teorias que mesclavam as contribuições dos filósofos gregos aos estudos dos escritos sagrados. Orígenes, teólogo cristão e filósofo (185-254), nascido em Alexandria, propôs uma explicação, segundo a qual, em Deus, a humanidade poderia ser aperfeiçoada, incentivada a melhorar, sendo que "um processo contínuo de lento avanço na direção da luz" integrava o cristianismo às doutrinas neoplatônicas. ${ }^{9}$ Segundo esse estudioso, o cristianismo era uma grande

\footnotetext{
${ }^{8}$ Concílio vem da "palavra latina concilium, oriunda da expressão cum calare (em grego, kalein), significa reunir. É uma reunião solene, liturgicamente organizada, destinada a estabelecer a doutrina, a disciplina e a prática do cristianismo [...] Enquanto a Igreja Católica admite 21 concílios, a Ortodoxa só reconhece os sete primeiros concílios ecumênicos realizados no Oriente". AZEVEDO, Antonio Carlos do Amaral. Dicionário Histórico de Religiões. Rio de Janeiro: Nova Fronteira, 2002, p. 105. Os 21 concílios foram: Nicéia (325); Constantinopla (381); Efèse (431); Calcedônia (451); Constantinopla II (553); Constantinopla III (680-681) Nicéia II (787) Constantinopla IV (869-870); Latrão I (1123); Latrão II (1139); Latão IV (1215); Lyon (1245); Lyon II (1274); Viena (1311-1312); Constance (1414-1418); Bale, Ferrara, Florença, Roma (1431-1445); Latrão V (1512-1517); Trento (1545-1563); Vaticano I (1869-1870); Vaticano II (1962-1965). In: (NOUVELLE ... 1989, p.1145).

${ }^{9}$ Neoplatônicas: "corrente filosófica do século III da era cristã, fundada por Amônio Sacas e divulgada por Plotino e seus seguidores Porfírio, Iâmblico e Proclo (séc. V). O neoplatonismo se caracteriza por uma interpretação espiritualista e mística das doutrinas de Platão, com influência do estoicismo e do pitagorismo. Segundo o Neoplatonismo, o real é constituído por três hipóstases - o Uno, a Inteligência (Nous) e a Alma, sendo que as duas últimas procederiam da primeira por emanação. É considerado um
} 
força moral que poderia mudar e aprimorar a sociedade, ajudando os homens a se tornarem mais dignos, úteis e responsáveis em termos sociais: "a mensagem cristã era dirigida a toda a humanidade e, em última instância, todos seriam acomodados no perdão e beneficência majestosos de Deus, tendo sido progressivamente purgados do mal. Assim, até o demônio e os anjos caídos acabariam por recuperar o Paraíso". ${ }^{10}$

O período em que a Igreja Católica buscava organizar seus cânones, como instituição, convivia com correntes teológicas e filosóficas que propunham projetos ideológicos utópicos para a organização comunitária e formação de cidadelas. Nesse sentido, ocorreu a aproximação e o apoio que do Estado imperial romano, delegando-se aos diáconos, bispos e presbíteros a responsabilidade pela ordem nas vilas e cidades que se consolidavam em meio ao caos dos últimos tempos do império romano. Por outro lado, torna-se pertinente retomar os motivos que levaram as autoridades imperiais romanas a investir seus esforços e recursos financeiros no cristianismo, segundo a concepção do catolicismo nascente, e rejeitar outras possibilidades concorrentes, ou diferentes interpretações, como o montanismo ${ }^{11}$, arianismo ${ }^{12}$ ou donatismo ${ }^{13}$. Confirmase, assim, que os movimentos denominados heréticos pela Igreja já eram combatidos, com fïmeza, desde o século IV da era cristã no sentido de buscar-se a universalização de uma crença, rejeitando-se os movimentos contrários, muitos dos quais se revelavam convincentes e poderosos. Para isso, contribuiu significativamente, a postura imperial

pensamento obscuro, embora tenha tido grande influência no início da formação do pensamento cristão, sobretudo devido ao espiritualismo". (In: JAPIASSU.Op. cit, 1991, p.178).

${ }^{10}$ JOHNSON, Paul. História do cristianismo. Rio de Janeiro: Imago, 2001, p. 135.

${ }^{11}$ Montanismo: "antiga seita cristã, de índole escatológica, originária da pregação de Montano, nascido na Frígia, no século II. Segundo pensava esse personagem, o cristianismo tornara-se muito popular, sendo necessário o restabelecimento de sua originalidade. Acompanhado de duas profetisas, Montano, ele próprio dotado de grande vocação profética, foi saudado como o Paráclito (Espírito Santo), o Consolador prometido por Cristo. Montano pregava um rigoroso ascetismo, na expectativa do Juízo Final, contestando energicamente o direito reivindicado pela Igreja em dar o perdão aos pecadores". In: AZEVEDO, Carlos do Amaral; GEIGER, Paulo. Dicionário Histórico de Religiões. Rio de Janeiro: Nova Fronteira, 2002, p. 264.

12 Arianismo: primeira grande heresia cristã assim denominada por se ter originado nas ideias professadas por Ário (256-336) que nasceu na Líbia e foi padre de Alexandria. O arianismo questionava a natureza de Jesus Cristo afirmando que o Filho, Pessoa da Santíssima Trindade, não era totalmente divino, não sendo co-eterno com o Pai, a primeira Pessoa, e sim apenas um filho, educado à imagem de Deus". Ibidem, p. 47.

${ }^{13}$ Donatismo: movimento carismático surgido no norte da África no decorrer do século IV sob a chefia do bispo de Cartago, Donato. Segundo os donatistas, um grande número de cristãos, para não serem perseguidos pelos romanos, entregou às autoridades municipais exemplares da Sagrada Escrituras e o mobiliário litúrgico das cerimônias cristãs, o que lhes valeu serem chamados de 'traditores' para os quais a comunidade cristã solicitava severa punição. (...) Nesse movimento, os cismáticos tinham no campesinato o setor mais radical. Ibidem, p. 134. 
de Constantino (272-337) ao se converter em 313 e, posteriormente, de Teodósio (408450), em decretar o cristianismo a religião oficial do Império Romano, no ano de 391.

Ao se situar a conversão de Constantino ao cristianismo, retoma-se a polêmica desse ato, explicado do ponto de vista religioso como a obtenção de uma graça - a vitória conseguida pelo imperador sobre Maxênio, nos arredores de Roma - e do ponto de vista da atitude do Estado romano em tolerar a prática cristã, reconhecendo o lado vantajoso que essa aproximação possibilitaria aos interesses políticos imperiais. Assim, a promulgação do Edito de Milão (313) "por meio do qual o Império Romano inverteu a política de hostilidade para com o cristianismo e concedeu-lhe pleno reconhecimento legal, foi um dos acontecimentos decisivos da história mundial." 14

Explicitando as razões dessa conquista, constata-se que nesse percurso de tempo - de Constantino a Teodósio - as autoridades imperiais perceberam os benefícios do cristianismo, à medida que se destinava a um grande público, de todas as raças e camadas sociais, bem como exigia o pagamento de impostos de acordo com o que Jesus pregava: "Daí a César o que é de César e a Deus o que é de Deus"; daí se retomar as reflexões de Tertuliano, escritor e jurista latino (155-222) sobre o crescimento do cristianismo, quase um século antes (ano 200): “os cristãos eram numerosos o bastante para derrubar o império, se suas intenções fossem hostis [...] Os cristãos eram [...] um elemento dócil e leal à sociedade". ${ }^{15}$

Essa adesão imperial à igreja cristã não ocorreu sem manifestações de experiências contestadoras, algumas delas conduzidas por lideranças que faziam da religião uma forma de atacar a dominação política romana, afirmando-se como portadoras do espírito divino. Em meio aos manifestantes encontravam-se pobres, analfabetos, monges entre outros excluídos. Essas rebeldias foram reprimidas pelas autoridades e algumas contaram com o apoio dos membros da Igreja.

No cômputo geral, no entanto, retoma-se que Igreja dos primeiros tempos abrigava, indiscriminadamente, os pobres e abandonados, seguindo os preceitos de Jesus Cristo. Por conseguinte, o público cristão cresceu numericamente, a ponto de representar uma ameaça ao poder político. Paralelamente a esse crescimento, a Igreja, como hierarquia, fortalecia-se, bem como reunia condições econômicas de manter suas funções nas dioceses e nos episcopados. Tratava-se, pois, de aceitar ou combater esse

\footnotetext{
${ }^{14}$ JOHNSON. Op. cit., p. 83.

15 JONHSON. Op.cit, p. 87.
} 
movimento o qual de espiritual passava também a abraçar as formas de organizações seculares, pois revelava estrutura hierárquica, domínio da economia, conservava as tradições, sem, no entanto, pretender criar um Estado secular que concorresse literalmente com o império romano.

Foi essa clareza que teve o imperador Constantino ao constatar e confirmar que os cristãos constituíam uma força, dentro do império, que almejavam a universalidade, sem, no entanto, defender a criação de um Estado próprio. Ao almejar a universalidade, eles se aproximavam das verdadeiras intenções do Estado romano. Nesse sentido, o imperador passou a fazer uma série de concessões ao clero, como isentá-lo dos impostos, o que colaborou para que as relações do Estado fiscalizassem as do clero, limitando sua autonomia, revertendo os poderes eclesiais em favor do império. Para reforçar essa tendência de secularização da Igreja, não faltaram as adesões absolutas de bispos que desfrutaram dessa situação privilegiada e ostentavam um modelo de riqueza semelhante ao das autoridades imperiais.

Assim, o lugar que a Igreja viria a ocupar no processo de reconstrução ocidental envolvia os aspectos sociais, políticos, econômicos, culturais, bem como o religioso. Portanto, desde os tempos imperiais romanos, seus integrantes organizavam-se em hierarquia, dominavam a leitura e a escrita, conheciam o grego e o latim e, por essas razões, estabeleciam laços também com as camadas aristocráticas.

Com as prerrogativas conquistadas, ou fornecidas pelo Estado, o cargo de bispo passou a ser disputado também pelos representantes das camadas aristocráticas. Logo, entre eles integrantes das camadas sociais abastadas, possuidoras de talentos e de conhecimentos na administração das terras, na ordenação do excedente, no domínio das técnicas e no registro da produção. Os bispos tornaram-se os arautos da economia, uma vez que administravam grandes latifúndios: "aos olhos bárbaros, os clérigos eram fazendeiros 'modernos', que mantinham uma contabilidade, planejavam o futuro e investiam. (...) $\mathrm{Na}$ sociedade germânica primitiva, parecia não haver nada similar a isso". 16

Por outro lado, a Igreja crescia com a acumulação de bens procedentes da doação de fontes diversas, entre as quais se encontravam as viúvas ou os homens ricos que legaram suas fortunas em favor do patrimônio religioso. Ao mesmo tempo, a

\footnotetext{
${ }^{16}$ Ibidem, p. 167.
} 
hierarquia eclesial ocupava-se de organizar a doutrina, estabelecendo os princípios, fiscalizando as práticas religiosas, revestindo-se, igualmente, das possibilidades ideológicas, o que preocupava as autoridades civis.

Esse saber eclesial, que incorporava aspectos da vida comum, foi difundido e reproduzido nas aldeias alodiais, apresentando efetivos resultados na drenagem dos pântanos, reaproveitamento de extensões de terras abandonadas, ocorrendo, então, a expansão da economia e o combate à fome: "Tal desenvolvimento não poderia ter ocorrido, ou por certo durado, se os clérigos não tivessem provado ser melhores que os agricultores e administradores de terras em geral". ${ }^{17}$

Esse mergulho na história medieval chama atenção para o papel que a Igreja ocupou no contexto da formação do Ocidente. Sugerindo o modelo de produção rural viável para a recuperação econômica, seus representantes atuavam também nos centros episcopais das cidades, oferecendo oportunidades para o crescimento da economia, possibilitando o reviver da função dos antigos centros urbanos.

Como negação a essa ostentação, por volta do século IV, evidenciavam-se manifestações de repúdio à Igreja e suas magníficas construções submetidas ao controle do Estado, que temia que o seu crescimento pudesse sobrepujar a autoridade civil:

O cristianismo tornou-se a fé majoritária em várias regiões do Ocidente, e o Estado começou a intervir em seus assuntos, inclusive no que concernia à doutrina. Certas vozes denunciaram a politização da Igreja e os compromissos que essa tendência acarretava. A reação de alguns dos mais fervorosos e mais engajados fiéis foi retirar-se. Tratava-se doravante de reascender a chama que havia animado a primeira geração dos cristãos. ${ }^{18}$

Esse movimento de lançamento das bases institucionais da Igreja particularmente nas cidades, onde o episcopado exercia o poder - ocorria no Ocidente, enquanto no Oriente, no mesmo tempo (desde o século III) irrompiam as experiências diversas de contestação a essa aproximação dos poderes espirituais e temporais, bem como ao desvirtuamento das autênticas vivências cristãs. Retomando, o que já foi abordado logo no início deste estudo, foi nesse contexto, que ocorreu a fundação dos cenóbios pelos mais antigos monges.

\footnotetext{
${ }^{17}$ Ibidem, p. 167.

${ }^{18}$ LE GOFF, Jacques; SCHMITT, Jean-Claude. Dicionário temático do Ocidente Medieval. Bauru/São Paulo: EDUSC, 2006.
} 
Possivelmente em outros pontos do Império ocorreram experiências semelhantes, como tentativa das pessoas buscarem um modelo de vida que as preservasse dos males que marcavam a sociedade europeia, no final da antiguidade e início da Idade Média. Ou seja, no sentido mais amplo, com a morte dos apóstolos, as comunidades cristãs tenderam a afrouxar suas práticas religiosas, incorporando hábitos pagãos, tornando o cristianismo distanciado do modelo dos primeiros cristãos. Os que desejavam manter sua fé afastaram-se, então, para os locais isolados:

(...) pouco e pouco, separados da multidão dos crentes, pelo fato de se absterem de matrimônio e de se manterem afastados de seus parentes e da vida deste mundo, foram chamados de monachi $^{19}$ pela austeridade de sua vida solitária e sem família. As comunidades que se formaram valeram-se do nome de cenobitas e suas celas e os seus aposentos foram denominados de cenóbios. ${ }^{20}$

Estudos apontam que esses modelos de comunidades monásticas teriam chegado ao Ocidente pelas rotas comercias que se estabeleceram na Antiguidade Tardia, encontrando adeptos que também buscavam modelos de ascese individual. Um dos primeiros cenóbios data do século IV, quando São Martinho (316-397) ${ }^{21}$ com seus oito companheiros "viviam em penhascos ribeirinhos em Marmoutier". Segundo seus biógrafos, esse monge teria exercido um papel significativo na pregação do evangelho, combatendo os pagãos e realizando milagres, tornando-se um personagem conhecido e idolatrado na França, sendo incorporado na criação de inúmeras igrejas em seu louvor.

\footnotetext{
19 "O termo monge e as palavras aparentadas derivam de uma raiz grega significando 'só', o que pende para uma significação mais social do que espiritual. É certo que a palavra eremita, derivado da palavra grega significando 'deserto', tornou-se o termo privilegiado para designar os ascetas solitários, enquanto 'monge' paradoxalmente, acabou qualificando os ascetas devotos que viviam em companhia de seus semelhantes em comunidades religiosas (coenobia). (...) Os frades também viviam em comunidades, apesar das diferenças significativas em relação as de seus predecessores monásticos. O conjunto destas comunidades religiosas cobria toda uma série de realidades, as congregações instaladas em meio aos homens e engajadas na vida social contrastavam com grupos de religiosos vivendo em isolamento total"(LE GOFF, 2006, p. 225).

${ }^{20}$ MICCOLI, Giovanni. Os monges. In: LE GOFF, O homem medieval. Lisboa: Estampa, 1985, p. 35.

${ }^{21} \mathrm{O}$ nome Martinho vem de Martem tenens, 'aquele que tem Marte', isto é, que faz guerra contra os vícios e os pecados. "Ou de martírum unus, 'um dos mártires', pois ele foi mártir pela vontade e pela mortificação da carne. Martinho pode ainda ser interpretado como 'excitante', 'estimulante', 'dominante' ....) Martinho (...) serviu como militar com seu pai, tribuno dos soldados sob os césares Constantino e Juliano. Ele teria desejado viver no deserto mas foi obrigado a se tornar militar no lugar". In: VARAZZE, Jacopo de. Legenda Áurea: a vida dos santos. São Paulo: Companhia das Letras, 2003, p. 928.
} 
Essa tendência também foi reforçada por meio das narrativas de viajantes e monges que conheceram a vida no Oriente e a divulgaram no Ocidente. João Cassiano (360-435) foi um desses personagens que, adepto da vida monástica, sistematizou uma regra, a qual deveria ordenar a vida comunitária, no início do século $\mathrm{V}$, fundando na região de Marselha, dois mosteiros, um masculino e um feminino.

Esse monge acreditava que só o exemplo rigoroso dos primeiros cristãos poderia devolver à sociedade um modelo de perfeição que a salvasse das contaminações pagãs. Para isso, defendia "a opção do celibato, a ascese, a renúncia a todas as formas de propriedade privada, com a consequente comunização dos bens ${ }^{22}$ " que permitiria a retomada do lugar que, historicamente, o cristianismo passaria a ocupar, ao longo do tempo.

Num primeiro momento, a intenção de Cassiano era regulamentar as comunidades, dotando-as de uma regra, favorecendo a unidade de comportamentos sob a disciplina e orientação de lideranças disponíveis para o desempenho de tais funções. No entanto, o papel de Cassiano e suas formulações trouxeram outros condicionantes que foram de significativa importância para se pensar o lugar que os mosteiros passariam a ocupar na definição do modelo de vida europeu ocidental e na construção das tradições que se tornariam clássicas para estruturação política, econômica, cultural e religiosa da sociedade que se constituía. Uma delas diz respeito à organização comunitária que buscava a genuinidade dos primeiros cristãos, porém munida de uma regra, tendo a obediência, a disciplina ${ }^{23}$ e, consequentemente, a hierarquia, como fundamentos, o que a distinguia das outras formas de asceses espontâneas. Nesse aspecto, a proposta de Cassiano atribuía uma importância excepcional ao cultivo das virtudes pessoais, sugerindo aos integrantes das comunidades que "a prática de uma vida recta (...) exige que não se ouse a ser chefe quem não aprendeu a ser súdito, que não ordene obediência aos seus súditos quem não aprendeu a praticá-la com seus superiores". ${ }^{24}$ Essa advertência sugeria um modelo que se convencionou para as

\footnotetext{
${ }^{22}$ Idem, p. 35.

${ }^{23}$ Convém recordar Michel de Foucault no capítulo Corpos Dóceis da obra, Vigiar e Punir e a crítica que ele faz à formação do pensamento ocidental que tem na disciplina um de seus fundamentos como herança da presença monástica no Ocidente. FOUCAULT, Michel. Vigiar e Punir. Rio de Janeiro; Petrópolis: Vozes, 1997.

${ }^{24}$ Miccoli, p. 36.
} 
organizações monásticas daquela época, pois a "iniciativa ascética dá lugar à imitação ascética" ${ }^{25}$ o que se tornaria privilégio de poucas intenções.

A experiência monástica de Cassiano se deu nesse tempo de formação e fundamentação da Igreja como instituição, em razão da consolidação teórica dos argumentos cristãos, por parte de pensadores, os quais, vivendo esse período de alterações, preocuparam-se em mostrar à comunidade cristã esclarecida e aos interessados, de maneira geral, a concepção da cidade de Deus, dialogando com obras clássicas e com a Sagrada Escritura.

Essa fase da história da Igreja institucional se inscreve no quarto período do movimento denominado Patrística ${ }^{26}$ por contar com estudiosos que, posteriormente, foram considerados os Pais ou Padres da Igreja. Entre os que interessam para este estudo, merece destacar Santo Atanásio (295-373), Santo Ambrósio (340-397), São Jerônimo (347-420), São João Crisóstomo (349-407) e Santo Agostinho (354-430). Esses estudiosos distinguiram-se por características singulares que os lançaram na formação oriental e filosófica (Atanásio, Crisóstomo); na formação latina mais preocupada com aplicação prática dos princípios cristãos, concentrado seus trabalhos em centros episcopais de cidades como Milão (Ambrósio e Pacômio). Destaque especial ocupou Santo Agostinho, que se tornou bispo de Hipona, em Cartago, prosseguindo sua atuação para Roma e depois Milão.

Esses doutores da Igreja incluíram em sua trajetória de estudos teológicos práticas religiosas da vida de Igreja em geral e as experiências ascéticas. Eles fundaram comunidades monásticas, munidas de regras, mas, no decorrer do tempo, também exerceram o cargo de bispo, particularmente, em Roma e Milão.

O papel que esses pensadores desempenharam na história do cristianismo é fundamental para a construção da doutrina, seus alicerces, práticas litúrgicas e, consequentemente, para a definição dos sacramentos. Ainda que tenham incorporado muito das práticas pagãs, suas concepções representaram o triunfo do cristianismo

\footnotetext{
${ }^{25}$ Ibidem , p. 36.

${ }^{26}$ Patrística pode ser o período de formulação do pensamento cristão que se estende desde o século II, quando se organizam os primeiros pressupostos doutrinários cristãos, até o século VIII. Como movimento de construção teológica da Igreja, preocupa-se mais com os dogmas do que com a filosofia propriamente dita. O movimento foi contemporâneo ao último período do pensamento grego, com o qual tem contato profundo, mas, sobretudo como o teísmo, se difere do panteísmo. Sobre o tema ver: PADOVANI, Umberto; CASTAGNOLA, Luís. História da Filosofia. São Paulo: Melhoramentos, 2000, p. 201-254.
} 
contra as demais manifestações que formavam escolas e tinham seus adeptos. Paul Veine, estudioso da Antiguidade, afirma:

Entre la época de Cícerón y el siglo de los Antoninos se produio un gran acontecimiento mal conocido: la memorfosis de las relaciones sexuales y conjugales. Al término de esta memorfosis, la moral sexual pagana se muestra idéntica a la futura moral cristiana del matrimonio. Ahora bien, esta transformación maduró independientemente de cualquier influencia cristiana; estaba ya acabada cuando se difundió la nueva religión y se pude pensar, incluso, que los cristianos simplesmente de apropiaron de nueva moral de las postrimerías del paganismo. ${ }^{27}$

Essas considerações relacionam-se particularmente, à formação de uma moralidade cristã vinculada às concepções de sexualidade, utilização de métodos contraceptivos, realização de abortos e aos valores atribuídos à virgindade e à prática do celibato. Considera-se que muitos dos seguidores de Jesus eram casados, tinham filhos; o mesmo acontecia com mulheres que se dispunham a seguir o evangelho. Nesse sentido, era necessário estabelecer leis que padronizassem o comportamento e instituísse os valores morais. Os filósofos estoicos como, Sêneca ${ }^{28}$, inspiravam arquétipos morais que se articulavam plenamente aos interesses cristãos. Eles condenavam a vida desregrada, defendiam o casamento somente com a finalidade da procriação; da mesma forma condenavam os métodos contraceptivos e encaravam com pessimismo os prazeres sexuais. Essas ideias pagãs foram incorporadas pelo cristianismo no Ocidente, tendo os Padres da Igreja como seus porta-vozes e ardorosos defensores: "Las funestas ideas de Augustin en materia sexual há influido hasta el día de hoy. Defendia la transmisión del pecado original por el acto sexual. La moral sexual de Agustín es profundamente pesimista y negativa. Tenía uma baja esima, peyorativa, de las relaciones sexuales que no se fundamentan en la revelación". ${ }^{29}$

\footnotetext{
${ }^{27}$ BLÁZQUEZ, J. M. La moral sexual cristiana. ALVAR, Jaime et al. Cristianismo primitivo y religiones mistéricas. Madrid: Ediciones Cátedra, 1995, p.381.

28 Sêneca (4-65) nascido em Córdoba, na Espanha, o romano Sêneca ficou conhecido como filósofo estoico e pensador político. "Em seus livros De clementia, De benficiis, De otio, entre outros faz reflexões sobre a liberdade, justiça, tirania e a participação dos cidadãos na vida pública. Sua doutrina é coerente com moral estoica: os homens são iguais (contra a escravidão), os males são devido às paixões humanas (ambição, crueldade, sede de glória etc.) e o papel do soberano é o de encarnar a sabedoria realizando a ordem".(JAPIASSU, 1991, p. 222).

${ }^{29}$ BLAZQUEZ. Op.cit. p. 386.
} 
Uma vez que expunham um pensamento pessimista em relação à sexualidade, como a causa da decadência humana, eles concebiam virgindade como a mais perfeita das virtudes, como "um gênero angelical e uma preparação para a visão de Deus", considerando-a, assim, como superior ao matrimônio. As influências desses pensadores projetaram-se ainda em relação às representações simbólicas vinculadas à vida clerical, tais como: valorização da hierarquia, padronização das vestes, culto às relíquias, exigências de habilidades intelectuais para os que aspirassem à vocação.

Dessa forma, como instituição, a Igreja nascente se configurou como uma resposta para a crise generalizada que se projetava por volta do século $\mathrm{V}$, quando não havia mais imperador que pudesse responder pelo governo, diante da complexidade que se instalava:

\begin{abstract}
A estrutura social do Império Romano, em que as camadas populares eram cada vez mais esmagadas por uma minoria de ricos e poderosos, explica o êxito das invasões bárbaras. (...) Os pobres estão despojados, as viúvas gemem e os órfãos são pisados a pés, a tal ponto que muitos, incluindo gente de bom nascimento e que recebeu educação superior, se refugiam junto dos inimigos. Para não perecer à perseguição pública, vão procurar entre os Bárbaros a humanidade dos Romanos, pois não suportam mais entre os Romanos a desumanidade dos Bárbaros. (...) Assim, emigram (...) para outros bárbaros que em toda parte dominam e não têm do que arrepender-se com o auxílio. Pois gostam mais de viver livres sob a aparência da escravidão que de ser escravos sob aparência da liberdade. ${ }^{30}$
\end{abstract}

O historiador francês Jacques Le Goff afirma que os tempos foram de confusões, pois na trajetória migratória dos germânicos muitos haviam se subjugados, outros combatidos entre si; outros ainda se misturaram formando "confederações efêmeras". Coincidindo com esses transtornos, o surto de doenças atingiu regiões da Espanha, Itália e da Gália causando inúmeras mortes, como retrata a literatura da época:

O Ocidente, como um todo, tornou-se uma área de povoamento tribal, em que reinos semibárbaros existiam por trás de fronteiras flutuantes (... ) a Igreja ocidental viu-se como legatária restante da cultura e da civilização romanas e o único canal por meio de que estas poderiam ser transmitidas para as novas sociedades e instituições europeias. Desse modo, defrontava-se com um desafio e uma oportunidade maior que na época da conversão de

\footnotetext{
${ }^{30}$ LE GOFF, Jacques. A Civilização do Ocidente Medieval. Lisboa: Estampa, 1983, p. 36
} 
Constantino. Tinha a chance de recriar a estrutura secular da sociedade $a b$ initio - e à sua própria imagem cristã. ${ }^{31}$

Conforme afirma Jacques Le Goff: "Algumas pessoas não viam diferenças entre bispos e magistrados romanos e atribuíam-lhes o essencial dos vários compromissos da Igreja com as grandes instituições sociais e políticas daquela época". ${ }^{32}$ Essa fusão de papéis possibilitou que o bispo católico assumisse um lugar privilegiado na gerência do caos:

Ele organizava as defesas, dirigia a economia de mercado, presidia a justiça, negociava com outras cidades e governantes. Quem eram esses bispos? Eram membros proeminentes da antiga classe dominante romana. Famílias romanas aristocráticas, proprietárias de terras e do alto funcionalismo público, vinham se infiltrando nos escalões superiores da Igreja desde o século IV - talvez até antes. ${ }^{33}$ Isto é: "O episcopado sub-romano ou pós-romano na Itália e na Gália, encontrava-se, basicamente, nas mãos da classe alta. ${ }^{34}$

Essa liderança dos bispos nos assuntos seculares estava presente por ocasião dos concílios quando, os membros da Igreja mais se envolviam em resolver questões gerais, em que se incluíam os assuntos do reino, da vida e dos costumes dos seus habitantes. Nessa trajetória, o bispo de Roma começou a se destacar, ainda que com dificuldades, ante o poder que os demais episcopados desfrutavam e a consequente dispersão da Igreja. Os papas, como, por exemplo, Gregório Magno I, (540-604), buscavam documentar manuscritos e demais fontes que acenavam para consolidar a Igreja como instituição, avançando nas questões seculares, decidindo sobre as leis dos reinos que se constituíam, muitos deles orientados pelos direitos consuetudinários, revestindo-os da perspectiva cristã.

O papa Gregório Magno viveu num tempo pontilhado de experiências cenobíticas, sendo que ele mesmo havia transformado sua casa, no Aventino, em lugar de retiro onde levava um modelo de vida austera. O exemplo cenobítico era também partilhado por Cesário de Arles (513-542), que fundou um mosteiro para mulheres em

\footnotetext{
${ }^{31}$ JOHNSON. op. cit, p. 153.

${ }^{32}$ LE GOFF, Jacques; SCHMITT, Jean-Claude. Dicionário Medieval. v. 2. Bauru: Edusc, p. 227.

33 JOHNSON, op. cit. p. 155.

${ }^{34}$ Ibidem, p. 155.
} 
512; já Cassiodoro (450-581) tinha preferência pelos escritos, edificou outra unidade monástica com destaque à cultura e divulgação da literatura cristã; Bento de Núrsia (480-547) criou o mosteiro de Monte Cassino e elaborou uma regra com base em outra mais antiga, a Regra do Mestre. Por volta de 600 existiam centenas de unidades monásticas espalhadas pela Gália.

Mas foi, sem dúvida, Gregório Magno quem teria promovido a divulgação da Regra de São Bento e da organização monástica nos moldes de seu fundador. Ele foi o papa que corou de glórias a iniciativa de Bento de Núrsia, concebendo a regra como um exemplo a ser seguido por outros mosteiros, em tempo de existência de muitas experiências. Isto porque, ao analisar a regra beneditina, Gregório Magno teria sido arrastado pelo perfil da Regra, no sentido de revelar clareza, praticidade, equilíbrio e bom senso evidentes nas propostas de seu fundador. A regra do monge de Mosteiro de Monte Cassino era de fácil compreensão e assim poderia ser utilizada na conversão dos pagãos ou de grupos ainda resistentes, como por exemplo, os habitantes da Irlanda. Com essa intenção, o papa encaminhou um grupo de monges para divulgar essa regra no norte da Europa, particularmente na Irlanda, um reino cristão que já havia sido convertido por São Patrício (387-461), mas que vivia uma experiência isolada sem muita relação com a Igreja de Roma.

A experiência cristã na Irlanda era semelhante à vida que os monges levavam em alguns pontos da Europa, como a comunidade de Martinho de Tour, na França. Ou seja, por ser uma ilha, a Irlanda e seus integrantes, isolados do continente europeu, não dispunham dos recursos como os romanos, o que os levou à vivência comunitária movida pela oração, práticas de piedade, estudos avançados e observação rigorosa da Sagrada Escritura. Também esses monges desejavam restaurar o modelo de vivência das comunidades cristãs primitivas, optando por uma pobreza exemplar: evitavam jantares de luxo, não andavam a cavalo, porque era ostentação; ao invés disso usavam asno como meio de transporte para imitar o exemplo de Jesus, ou escolhiam pregar o evangelho a pé, seguindo as maneiras dos antigos apóstolos. Esse era o espírito dos monges irlandeses, ao qual associavam ainda profundo conhecimento das Sagradas Escrituras, evidenciado talento artístico e requintada erudição: "suas casas rudimentares de pedra sem argamassa eram despretensiosas por fora, mas guardavam grandes 
tesouros. E acima de tudo, eram nômades". ${ }^{35}$ Eles até mesmo se impunham contra Roma possuindo um calendário litúrgico diferente do oficial.

O conhecimento da regra enviada pelo papa não trouxe uma adesão imediata. A conversão efetiva dos povos do Norte exigiu ainda a intervenção ou a influência de outros personagens, como Beda “o Venerável” $(674-735)^{36}$, para que as conversões dos antigos celtas e saxões lograssem êxito, o que ocorreu por volta do século VIII. ${ }^{37}$

Assim, posteriormente, as relações entre as partes acabaram por fomentar o crescimento das comunidades e a expansão do cristianismo, de acordo com as concepções romanas. Essa aproximação ganhou um novo impulso com a vinda de São Columbano, ${ }^{38}$ que procedente da Irlanda, expandiu o monaquismo para outras partes da Bretanha, Alemanha e parte central da Europa.

Gregório Magno tornou-se então um apreciador da regra beneditina e a teria utilizado como uma excelente estratégia para a expansão do cristianismo e ordenação da Igreja ainda dispersa em mãos de inúmeros episcopados que se fortaleciam e concorriam com o poder papal. À medida que ela ia sendo implantada, a economia crescia e os monges se fortaleciam, tornando-se grandes latifundiários e senhores da oração e intermediários das intenções das camadas aristocráticas.

\footnotetext{
${ }^{35}$ Ibidem, p. 174. E ainda os monges eram marinheiros, viviam apenas de peixe, sepultavam os corpos no mar. São Brandão era um desses monges, que teria fundado o mosteiro de Clonfert, em Galway. Faleceu em 580, sendo que suas histórias de viagens foram muito admiradas na Europa e traduzidas para o francês, provençal, alemão, italiano e norueguês.

${ }^{36}$ Jacques Le Goff afirma: "Certos homens, pelo seu saber, foram também, entre os séculos V e VIII, faróis que por muito tempo iluminaram a noite medieval. K. Rand chamou-lhes de 'fundadores da Idade Média'. A função de todos, ou quase todos, consistiu na salvação do essencial da cultura da Antiguidade, colhendo-a sob forma assimilável pelos espíritos medievais e dando-lhe a necessária roupagem cristã". Segundo este historiador, "há quatro que sobrelevaram os outros: Boécio (c. 480-524), Cassiodoro (c.480573), Isidoro de Sevilha (c. 560-636) e Bede (c. 673-735)". De acordo com esse historiador, a Boécio a Idade Média deve tudo o que se sabe acerca de Aristóteles até meados do século XII, ou seja, sobre a lógica e os fundamentos iniciais para a formação da escolástica, bem como o que se sabe sobre a música relacionada ao ideal grego. A Cassiodoro, entre outras contribuições, coube a iniciativa de fixar aos monges (do convento de Vivarium) a incumbência de copiar os manuscritos antigos, o que inspirou os futuros scriptoriuns monásticos. Isidoro de Sevilha deixou entre outras contribuições, o programa de artes liberais, o vocabulário das ciências, a crença de que os nomes são as chaves da natureza das coisas e que a cultura profana é necessária para a boa compreensão da Sagrada Escritura. Bede legou a ideia da multiplicidade de sentido da Escritura e orientações para a astronomia e cosmografia. In: LE GFF, Jacques. A civilização do Ocidente Medieval. v. 1, Lisboa: Estampa, 1983, p. 164-167.

37 Beda o "Venerável" escreveu "A História da Igreja e da Nação Inglesa" explicitando como o cristianismo chegou à Inglaterra e o progresso que se registrou na Igreja. Ele associa o surgimento da Igreja e da história do povo inglês.

${ }^{38}$ São Columbano, nasceu em 540, seguiu o estilo dos monges irlandeses, demonstrando erudição no conhecimento dos clássicos. Era extremado em divulgar o cristianismo rigoroso. Seus adeptos "vestiam longos hábitos brancos, nada mais, carregavam cajados recurvados e seus livros litúrgicos empacotados em sacolas de couro à prova d' água; e, em torno do pescoço, tinham garrafas d'água e bolsinhas com relíquias e hóstias consagradas" ( JOHNSON, 2001, p. 174).
} 
Os nobres e cavaleiros passaram então a se identificar como "cristãos por procuração", pois dependiam das orações e das práticas de piedade vivenciadas no interior das celas. Para isso tornavam-se famílias doadoras, as quais retribuíam as graças alcançadas ou as vitórias nas guerras fazendo concessões de tesouros, doando terras ou incentivando seus filhos a seguirem o monaquismo, pois era a oportunidade de estar mais perto de Deus e de se santificar.

A santidade era uma intenção que se modificava em razão dos tempos conturbados e afetados por inúmeras crises. Os primeiros santos eram os mártires perseguidos pelo Estado Romano, tais como Pedro e Paulo, cujos túmulos, no subsolo romano, enchiam Roma de orgulho e a legitimava, verdadeiramente, como sendo a sede da Igreja. Outros bispos apoiavam essa prática e buscavam encontrar os túmulos de cristãos e sobre eles construir um templo para atrair a população ao culto e assim também ordenar e enriquecer a cidade, povoá-la e torná-la legitimamente forte, bem como o seu bispo.

\section{Conclusão}

Com a expansão da Igreja e dos mosteiros, as ideias de santidade $^{39}$ passaram a

39 André Vauché afirma que o culto dos mártires "“democratiza-se através do santo patrono, que baseia as suas características na relação de clientela: lealdade do protegido, 'amizade' e dever de proteção por parte do patrono em relação a quem a ele se recomendou". A retomada da figura do santo e o culto aos seus milagres surgiam como uma possibilidade de manter vínculos de identidade entre uma coletividade que se via ameaçada de desintegração, considerando os fatores que interagiam: guerras, fome, doenças, saques, contato entre diferentes povos. E Vauché afirma: "Assim se explica não só a falsificação das catacumbas romanas por parte do papa Dãmaso, mas também a invenção [grifos do autor] das relíquias dos santos Gervásio e Protásio, em Milão no na o de 385, e sua apropriação imediata por parte de Ambrósio, em favor da igreja episcopal. Ao tornar-se patronus celeste da catedral e da cidade, o santo reforçava o prestígio de seu representante e, em breve, seu sucessor: o bispo". VAUCHÉ, André. O santo. In: LE GOFF, Jacques (dir.). O homem medieval. Lisboa: Estampa, 1989, p.211-230. A invenção dos milagres e a eleição dos patronos das cidades e consequentemente - dos santos ofereceriam a oportunidade e a possibilidade de integrar grupos sociais dispersos, tais como pobres, estrangeiros, mulheres, camponeses e reunilos em torno de uma mesma prática o que os assemelhava e suavizava as diferenças, estabelecendo redes de controle e de poder sobre a sociedade. Nesse sentido, as procissões aos lugares sagrados, a evolução dos rituais e a padronização da liturgia tornaram-se exemplos efetivos dessas práticas religiosas e culturais. Da mesma forma elevaram-se construções de igrejas para o culto aos santos, transpondo-se as relíquias 
valorizar os que professavam a ascese e profunda espiritualidade. A imagem do monge isolado corporalmente da família e da sociedade, entregue à oração e as demais práticas litúrgicas - o canto, a lectio divina, a salmodia -, além do testemunho da obediência e castidade, surgia como o novo modelo de santidade. Eles renunciavam às maldades da sociedade, tornando-se homens puros capazes de comunicar-se com Deus, sendo, assim, os porta-vozes dos que estavam no mundo, revelando-lhes o caminho da santificação. Além do mais, conheciam as Sagradas Escrituras, portanto, sabiam ler e escrever, constituindo imensas bibliotecas, dotadas de scriptorium, em que se reproduziam obras do mundo cristão e pagão. Eram pessoas cultas, muitas das quais se tornaram monges copistas e desempenharam uma importante tarefa na reprodução, tradução e conservação dos documentos antigos. Portanto, sabiam ler e conheciam a verdade, e desta forma distinguiam-se da maioria analfabeta e campesina. Os mosteiros cresceram e se fortaleceram como uma possibilidade de formação do clero, porém vinculados às camadas privilegiadas. Reis e nobres desejaram ser sepultados com as vestes dos monges na esperança de serem reconhecidos como santos na vida depois da morte.

dos cemitérios para os santuários e altares. No reconhecimento e apropriação do culto aos santos, os monges do deserto - eremitas ou anacoretas - igualmente desempenharam um papel fundamental, à medida que divulgavam um comportamento diferenciado, expondo-se a uma série de mutilações, tais como a fome, o frio, a recusa aos cuidados do corpo e ostentação, demonstrando resistência e a vivência das virtudes na sua relação com os outros. Revelavam-se, com seu exemplo, "seres extraordinários" e a sua constância na oração os aproximava das concepções do divino o que lhes conferia prestígio e um lugar na ordem do sobrenatural. Esse reconhecimento se aprofundou com as obras de alguns monges - por exemplo, São Martinho - o qual, além das virtudes da renúncia comuns aos monges, evidenciou uma grande preocupação na conversão dos pagãos, na defesa da evangelização e na divulgação da autêntica vida cristã, cujo testemunho de santificação obtinha-se por meio da prática das virtudes ascéticas, sem ocorrer o derramamento de sangue. $\mathrm{O}$ mosteiro por ele criado às margens do Rio Loire tornou-se uma escola eclesiástica e funcionou como um "viveiro de bispos", contribuindo para o fortalecimento do papel do bispo, consequentemente do papa. 


\section{Referências}

AZEVEDO, Carlos do Amaral; GEIGER, Paulo. Dicionário Histórico de Religiões. Rio de Janeiro: Nova Fronteira, 2002.

BERLIOZ, Jacques. Monges e religiosos na Idade Média. Lisboa: Terramar.

BLÁZQUEZ, J. M. La moral sexual cristiana. ALVAR, Jaime et al. Cristianismo primitivo y religiones mistéricas. Madrid: Ediciones Cátedra.

FOUCAUlT, Michel. Vigiar e Punir. Rio de Janeiro; Petrópolis: Vozes, 1997.

JOHNSON, Paul. História do cristianismo. Rio de Janeiro: Imago, 2001.

LE GOFF, Jacques. A Civilização do Ocidente Medieval. Lisboa: Estampa, 1983.

LE GOFF, Jacques; SCHMITT, Jean-Claude. Dicionário Medieval. v. 2. Bauru: Edusc.

LE GOFF, Jacques; SCHMITT, Jean-Claude. Dicionário temático do Ocidente Medieval. Bauru/São Paulo: EDUSC, 2006.

MICCOLI, Giovanni. Os monges. In: LE GOFF. O homem medieval. Lisboa: Estampa, 1985.

PADOVANI, Umberto; CASTAGNOLA, Luís. História da Filosofia. São Paulo: Melhoramentos, 2000.

VARAZZE, Jacopo de. Legenda Áurea: a vida dos santos. São Paulo: Companhia das Letras, 2003.

Recebido: 14/11/2015

Received: 11/14/2015

Aprovado: 03/12/2015

Approved: 12/03/2015 